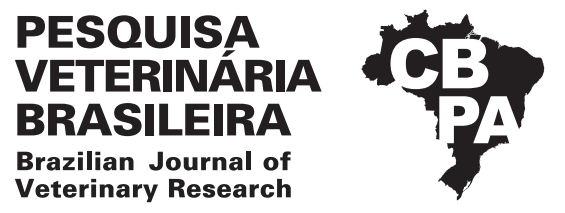

Pesq. Vet. Bras. 39(7):469-475, July 2019 DOI: 10.1590/1678-5150-PVB-6256

Original Article

ISSN 0100-736X (Print)

ISSN 1678-5150 (Online)

\title{
Equine pythiosis in the eastern wetlands of Uruguay ${ }^{1}$
}

\author{
Agustín Romero², Juan García², Sofía Balestié ${ }^{3}$, Felipe Malfatto ${ }^{3}$, \\ Alejandra Vicentino ${ }^{3}$, Elisa Simone V. Sallis ${ }^{4}$, Ana Lucia Schild ${ }^{5}$ (D) \\ and Fernando Dutra ${ }^{2 *}$ (1)
}

\begin{abstract}
Romero A., García J., Balestié S., Malfatto F., Vicentino A., Sallis E.S.V., Schild A.L. \& Dutra F.Q. 2019. Equine pythiosis in the Eastern wetlands of Uruguay. Pesquisa Veterinária Brasileira 39(7):469-475. DILAVE Miguel C Rubino, Laboratorio Regional Este, Avelino Miranda 2045, CP 33000, Treinta y Tres, Uruguay. E-mail: fdutraquintela@gmail.com

Equine pythiosis is an ulcerative and granulomatous disease of the skin, caused by the oomycete Pythium insidiosum (Pythiaceae). The objective of this study was to describe seven cases of equine pythiosis that occurred from 2012 to 2017 in the eastern region of Uruguay. Six of the seven cases occurred in the eastern wetland ecosystems of the Merin basin, and the remaining case occurred in the wetland fluvial plains of the Tacuarembó River. Lesions consisted of a large, rapidly growing ulcerated tumor with abundant granulation tissue, serosanguineous secretion, and fistulous tracts containing large concretions or kunkers. The animals presented intense pruritus, claudication and loss of body condition, with death or euthanasia in extremis in six cases. The main histological lesions consisted of an eosinophilic and pyogranulomatous inflammatory process, with numerous foci of eosinophilic necrosis (kunkers), collagenolysis, and a Splendore-Hoeppli reaction. In all cases, silver coloration (Grocott) showed intralesional hyphae compatible with P. insidiosum, which was confirmed by immunohistochemistry in three cases. A horse in the terminal phase of the disease was treated with triamcinolone acetonide (50mg IM every 15 days), and fully recovered after 1 year. It is concluded that equine pythiosis is prevalent in the wetland ecosystems of eastern Uruguay and that treatment with triamcinolone is auspicious.
\end{abstract}

INDEX TERMS: Equine, Pythium insidiosum, pythiosis, eastern wetland, Uruguay, horses, pathology.

\begin{abstract}
RESUMO.- [Pitiose equina em áreas úmidas do leste do Uruguai.] Pitiose é uma doença granulomatosa e ulcerativa da pele dos equinos causada pelo oomyceto Pythium insidiosum (Pythiaceae). 0 objetivo deste trabalho foi descrever sete casos de pitiose equina que ocorreram de 2012 a 2017 na região leste do Uruguai. Seis dos sete casos ocorreram no ecossistema de áreas pantanosas da bacia da bacia da Lagoa Mirim Merin e o restante nas planícies fluviais pantanosas do rio Tacuarembó. As lesões se caracterizaram por tumores
\end{abstract}

\footnotetext{
${ }^{1}$ Received on February 13, 2019.

Accepted for publication on April 1, 2019.

2 DILAVE Miguel C Rubino, Laboratorio Regional Este, Avelino Miranda 2045, CP 33000, Treinta y Tres, Uruguay. ${ }^{*}$ Corresponding author: fdutraquintela@gmail.com

${ }^{3}$ Veterinarian, Arredondo 1044, Rio Branco, Uruguay.

${ }^{4}$ Departamento de Patologia, Faculdade de Veterinária, Universidade Federal de Pelotas (UFPel), Campus Universitário Capão do Leão, Pelotas, RS 96010-900, Brazil.

${ }^{5}$ Laboratório Regional de Diagnóstico, Universidade Federal de Pelotas (UFPel), Campus Universitário Capão do Leão, Pelotas, RS 96010-900.
}

ulcerados de crescimento rápido com abundante tecido de granulação, secreção serossanguinolenta e presença de tratos fistulosos contendo material coraloide ou kunkers. Os equinos apresentavam prurido intenso, claudicação e perda da condição corporal e seis morreram ou foram eutanasiados in extremis. As principais lesões histológicas consistiam de um processo inflamatório piogranulomatoso com numerosos focos de necrose eosinofílicos (kunkers), colagenólise e reação de Splendori-Hoepli. Em todos os casos a impregnação pela prata (Grocott) revelou a presença de hifas intralesionais compatíveis com $P$. insidiosum, o que foi confirmado pela imuno-histoquímica em três casos. Um equino em fase terminal da doença foi tratado com triamcinolona acetonida $(50 \mathrm{mg}$, IM, a cada 15 dias), recuperando-se completamente após um ano. Conclui-se que a pitiose é uma enfermidade presente em áreas úmidas na região leste do Uruguai e o tratamento com triamcinolona pode ser uma alternativa promissora.

TERMOS DE INDEXAÇÃO: Equinos, Pythium insidiosum, pitiose, região úmida, leste uruguaio, Uruguai, patologia. 


\section{INTRODUCTION}

Pythiosis, also known as "leeches" in the US, "swamp cancer" in Australia, "bursattee" (i.e. rainy season) in India, "hyphomycosis destruens" in southeast Asia, and "Mal dos Pantanos" in Brazil, is a lethal granulomatous cutaneous disease of horses, caused by the aquatic fungus-like oomycete Pythium insidiosum (kingdom Stramenopila, family Pythiaceae) (Santos et al. 2011, Grooters 2013). Pythiosis sporadically occurs in canines, cats, ruminants and humans, although it is not considered to be a disease with zoonotic potential (Gaastra et al. 2010, Mauldin \& Peters-Kennedy 2015). The cutaneous/subcutaneous form of pythiosis is the most commonly described form in horses (Chaffin et al. 1995, White et al. 2008, Grooters 2013), although intestinal, nasal and pulmonary cases have also been reported (Goad 1984, Allison \& Gillis 1990, Morton et al. 1991, Souto et al. 2016). The cutaneous/subcutaneous form may also involve the regional lymph nodes, or may invade the underlying bone and cause osteomyelitis of the lower limbs (Alfaro \& Mendoza 1990). No predilection of race, sex or age exists (Gaastra et al. 2010, Grooters 2013). The disease is found worldwide (especially in Australia, India, Thailand, and southern US), occurring with the highest incidence in tropical and subtropical regions associated with wetlands, dumps or swampy areas (Gaastra et al. 2010). In South America, an extensive series of cases has been reported in Colombia (Cardona-Álvarez et al. 2014), Venezuela (Márquez et al. 2010), and Brazil, particularly in the Pantanal Mato-Grossense (Pereira \& Meirelles 2007, Santos et al. 2011) and in lowland areas adjacent to the Merin and Patos lagoons (Marcolongo-Pereira et al. 2012).

Environmental conditions are the most influential factors for the occurrence of equine pythiosis. Pythium insidiosum requires a warm-water environment $\left(30-40^{\circ} \mathrm{C}\right)$ and an organic substrate of decaying vegetation in order to survive and reproduce (Gaastra et al. 2010). Zoospores show chemotaxis to decomposing plants, as well as to animal hair or damaged tissues. Once in the host, zoospores lose their flagella, encyst, develop germinal tubes, and invade tissues with the help of proteolytic enzymes (Mendoza et al. 1996). The lesions are usually located in the body parts most often in prolonged contact with contaminated water, such as the distal extremities, the ventral aspect of the thoraco-abdominal wall and the face (Grooters 2013, Mauldin \& Peters-Kennedy 2015). Lesions begin as small ulcerations that rapidly enlarge to become large tumor-like masses, with multiple fistulous tracts and pale yellow concretions similar to coral, called "kunkers" or "leeches" (Mauldin \& Peters-Kennedy 2015). The kunkers, a unique pathological finding of the equine species, exist microscopically in areas of necrosis with large numbers of degranulated eosinophils, collagenolysis, fibrosis, and a Splendore-Hoeppli reaction around P. insidiosum hyphae (Miller \& Campbell 1984, Martins et al. 2012). Hyphae are difficult to visualize histologically with hematoxylin and eosin (HE) and periodic acid-Schiff (PAS) staining, but are strongly positive to Grocott's methenamine silver (GMS), and can be confirmed with immunohistochemistry (Brown et al. 1988, Martins et al. 2012) or molecular methods (Azevedo et al. 2012).

The treatment of pythiosis is controversial. Surgically removing all affected tissue with a safety margin to avoid recurrences is often hampered in field horses by the size of the lesion, the risky anatomical regions that are typically involved and the high cost of the surgery (Grooters 2013). Surgery followed by immunotherapy is reported to be $70 \%$ effective (Pereira \& Meirelles 1997, Mendoza \& Newton 2005). Antimycotic chemotherapy with potassium iodine or amphotericin B generally fails because $P$. insidiosum is not a fungus and hence does not have ergosterol in its cytoplasmic membranes (Mendoza et al. 1996). Some authors point to the high efficacy of the use of amphotericin B in a $10 \%$ solution of dimethylsulfoxide by means of the intravenous distal regional perfusion technique (Dória et al. 2015). An earlier report of several horses cured following the use of the synthetic corticosteroid triamcinolone acetonide intramuscularly (Cuero-Castilla \& Mendoza-Espinoza 1985 apud Mendoza et al. 1996) was recently confirmed in a case-control study with $100 \%$ efficacy in 12 affected horses (Cardona-Álvarez et al. 2016, 2017).

Although Uruguay has favorable ecological conditions for the circulation and transmission of Pythium insidiosum (Machado et al. 2018), studies of this disease in Uruguay are scarce and limited to laboratory reports (Dutra et al. 2012, 2014). The objective of the present study was to describe the clinical, pathological and geographical distribution of a series of seven cases of equine pythiosis diagnosed in the eastern region of Uruguay from 2012 to 2017. The successful treatment of a case was also reported.

\section{MATERIALS AND METHODS}

A retrospective study of seven cases of pythiosis in horses diagnosed from 2012 to 2017 at the East Regional Laboratory of the DILAVE Miguel C. Rubino, Treinta y Tres, Uruguay, was conducted. Clinical, epidemiological and management data were collected during visits to the farms. Biopsies from the seven horses were fixed in a $4 \%$ aqueous solution of buffered formaldehyde, dehydrated in graded alcohol, cleared in xylene, embedded in paraffin, cut into $5 \mu \mathrm{m}$-thick sections and stained with hematoxylin and eosin (HE), periodic acid-Schiff (PAS), and Grocott's methenamine silver stain (GMS).

For the confirmation of Pythium insidiosum infection, paraffin blocks of all cases with suspicious lesions were immunolabelled using a polyclonal anti-P. insidiosum antibody produced in rabbits, using the streptavidin-peroxidase complex and chromogen 3,3 diaminobenzidine (DAB) (Brown et al. 1998). Immunohistochemistry (IHC) was performed at the "Laboratório Regional de Diagnóstico", "Universidade Federal de Pelotas", Pelotas/RS, Brazil.

One horse in the final phase of the disease and with an unfavorable prognosis (Case 7), was treated with triamcinolone acetonide as a last attempt to save the animal, with the agreement of the owner. The dosing protocol recommended by Cardona-Álvarez et al. (2016), $50 \mathrm{mg} / \mathrm{kg}$, IM, every 15 days, was followed. The animal was clinically evaluated every 15-20 days for 4 months and then followed-up sporadically until complete remission.

To investigate the geographic pattern of the disease, the seven cases were geolocated on the digital map of the Portal of the National Agricultural Information System (SNIA 2018), using, as geographical coordinates, the rural census track of the paddock where the animal was at the time of diagnosis. A one-to-one point map, with one point representing a single case, was created. In order to reveal the geographic pattern, the following geographic layers were superimposed on the point map: 1) topographic layer; 2) soil types layer (1: 1,000,000); 3) flooding layer (ordinally classified into six growing categories of flooding frequency and duration: occasional, very short, short, irregular long, regular long and very 
long); and 4) soil drainage layer (ordinally classified into eight increasing categories of drainage: poor, some poor to poor, some poor, moderate to some poor, moderate, good to moderate, good and excessive) (Molfino \& Califra 2004).

\section{RESULTS}

\section{Case description}

Table 1 shows the clinical and epidemiological data of the seven cases of equine pythiosis diagnosed in the Departments of Treinta y Tres, Durazno and Rocha. All cases occurred from March to June (late summer and autumn). Most of the horses were female (5/7), of the Criollo breed (6/7 cases) and adults (6/7 cases; 5-19 years), although an Arabian mare (Case 2) and a 7-month-old filly (Case 6) were also diagnosed. Two rice-livestock farms had a history of similar cases in previous years.

\section{Clinical signs and pathology}

All the affected animals showed rapid deterioration, extensive multifocal alopecia, pain, claudication, and severe pruritus in the affected areas. Lesions were located on the lower lip and chin (Case 1), upper lip and left nostril (Case 2), ventral abdomen (Case 5), distal forelegs (Case 3 and 6), and distal hindlegs (Case 4 and 7). The lesions appeared as large ulcerated masses, 15 to $40 \mathrm{~cm}$ or more, with an irregular surface and draining tracts that discharged thick strands of a serosanguineous fluid (Fig.1). Yellowish-white concretions, either embedded in the tissue or detached into sinus cavities, were found in all cases (Fig.2). Smaller satellite lesions were observed in horses with large limb lesions.

Histologically, in all horses, the epidermis was extensively ulcerated and covered by dried fibrin, bacteria and cellular debris. In the dermis and subcutaneous panniculus, there was extensive fibroplasia, with multifocal to coalescing areas of eosinophilic necrosis containing karyorrhectic cellular debris, occasional clear hyphal-ghost spaces, and numerous degranulating eosinophils encrusted on degenerating collagen fibers (collagenolysis) (Fig.3). Eosinophils, neutrophils, mast cells and macrophages surrounded these necrotic foci (Fig.4). Occasionally, there were giant cells and foci of Splendore-Hoeppli reaction. With GMS staining, a variable amount of irregular, sparsely septate hyphae with thick, parallel cell walls and branched at $90^{\circ}$ angles, was observed (Fig.5). Pythium insidiosum was confirmed by IHC in three of the seven cases (Case 2, 5 and 6). PAS staining was inconclusive or negative in all cases.

\section{Evolution and treatment of a case}

In six of the seven cases, the lesion extended rapidly over several weeks until death or euthanasia in extremis; none had responded to previous antibiotic or antifungal treatment. Horse treated with triamcinolone acetonide (Case 7) had a large lesion in the right hind limb, anemia ( $11 \%$ microhematocrit), and a very poor body condition previous to first dosing (Fig.6A). By 2 weeks after the first dosing, pruritus, bloody secretion and satellite lesions had disappeared, ulceration progressively regressed, the surface became smooth and pink, hematocrit increased to $28 \%$, and

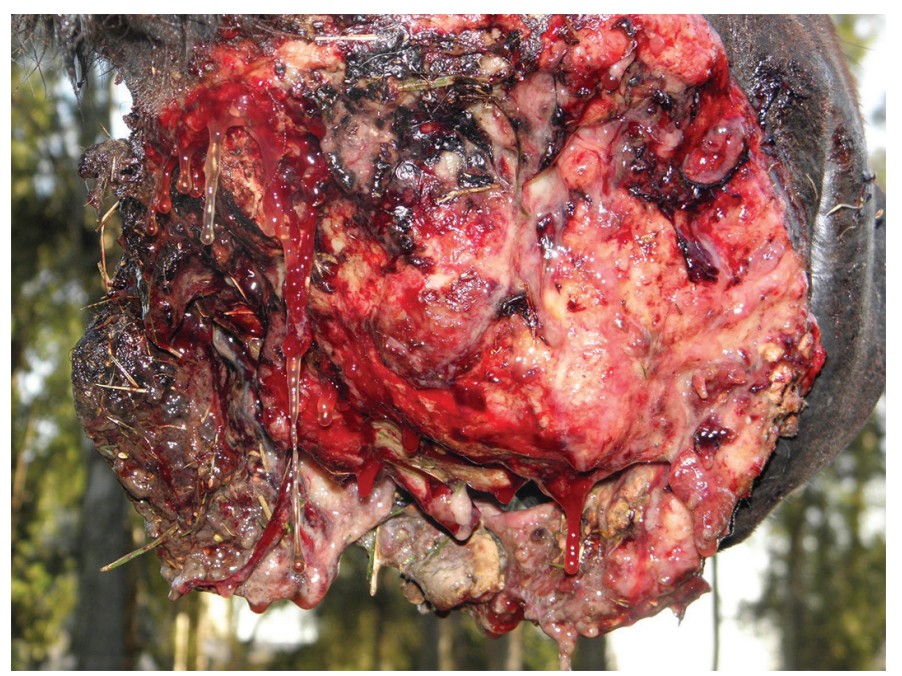

Fig.1. Case 1: Criollo mare. Ulcerated granulomatous growth in the lower lip and chin, with thick serosanguineous discharge.

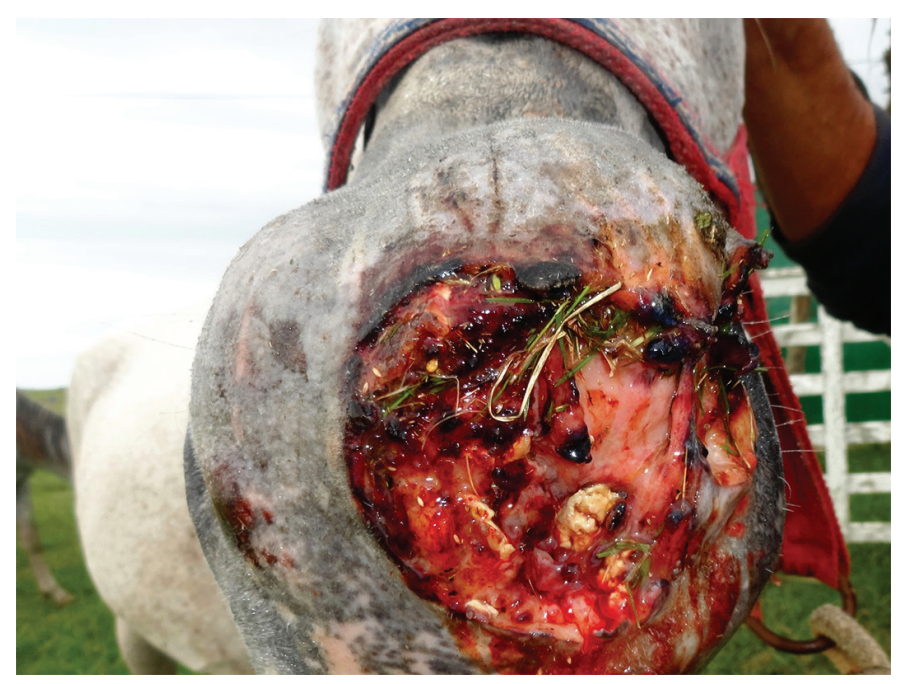

Fig.2. Case 2: Arab mare. Extensive ulcerated tumor in the upper lip and nasal fossa, with numerous detached kunkers (arrow).

Table 1. Cases of equine pythiosis in the eastern region of Uruguay (2012-2017)

\begin{tabular}{cccclll}
\hline Case & Category & Breed & Age & Department & \multicolumn{1}{c}{ Place } & Lesion location \\
\hline 1 & Mare & Criollo & 19 years & Treinta y Tres & Merin wetland & Lower lip, chin \\
2 & Mare & Arab & 5 years & Treinta y Tres & Merin wetland & Upper lip, nostrils \\
3 & Stallion & Criollo & 4 years & Treinta y Tres & Merin wetland & Left forelimb, fetlock \\
4 & Stallion & Criollo & 9 years & Rocha & Merin wetland & Right hindlimb, pastern \\
5 & Mare & Criollo & 12 years & Treinta y Tres & Merin wetland & Ventral abdomen \\
6 & Filly & Criollo & 7 months & Durazno & Negro River wetland & Right forelimb, cannon \\
7 & Mare & Criollo & 7 years & Treinta y Tres & Merin wetland & Right hindlimb, pastern and fetlock
\end{tabular}




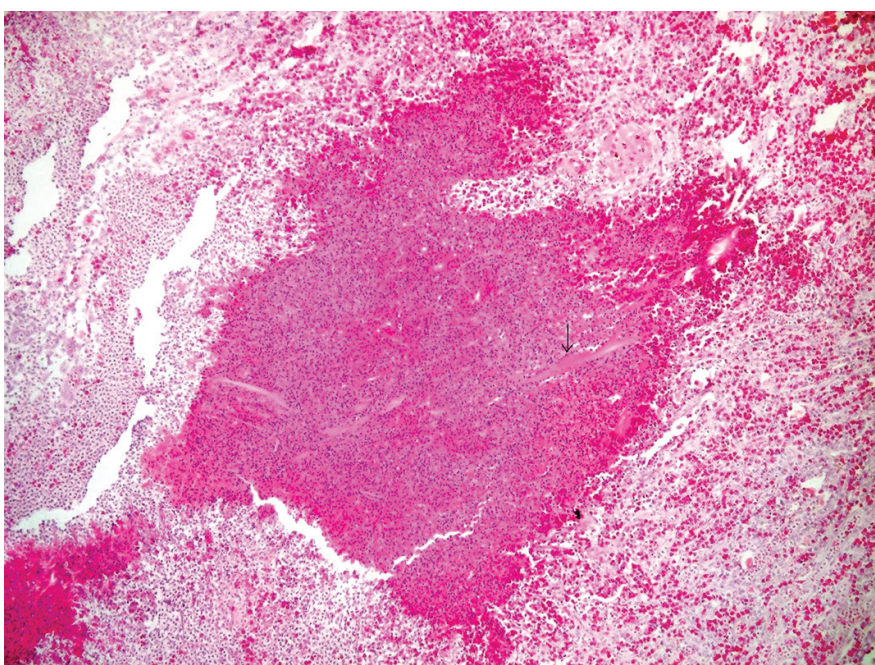

Fig.3. Case 3: Arab mare. Eosinophilic granuloma (kunker) with central amorphous necrosis and borders of macrophages and eosinophils in palisade. Degenerated collagen fibers are observed within the amorphous content (arrows). HE, obj.10x.

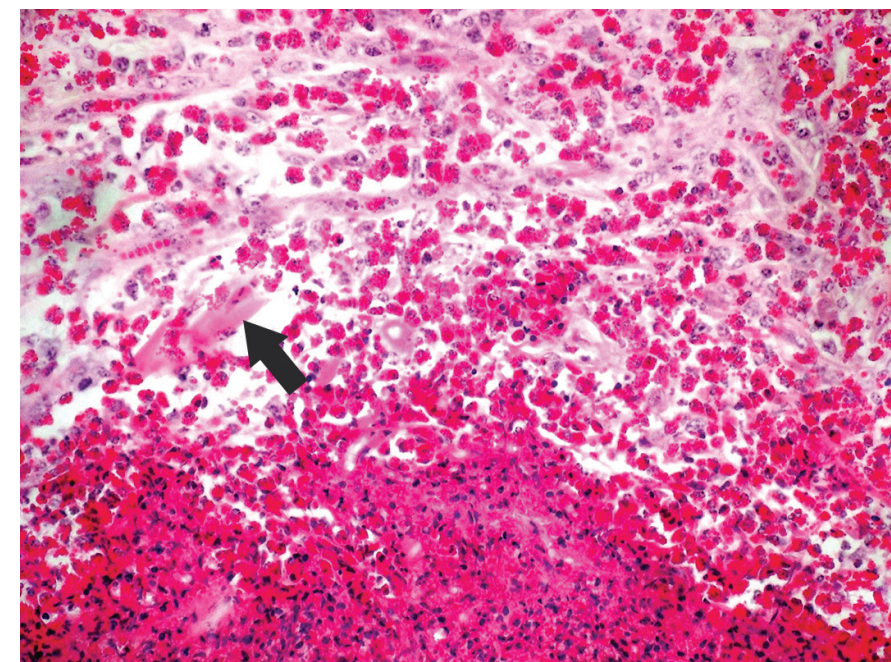

Fig.4. Case 3: Arab mare. Kunker edge showing a focus of amorphous necrosis (bottom-left), surrounded by numerous degranulated eosinophils around degenerated collagen fibers (top-right). HE, obj.40x.

the margins of the wound showed a rapid re-epithelization (Fig.6B,C). After 1 year, the wound was almost completely healed by secondary intention and the animal was discharged in very good body condition (Fig.6D).

\section{Geographic pattern}

The superposition of the topographic layer showed that six of the seven cases were located in the lower plains of the Merin lagoon basin in the departments of Cerro Largo, Treinta y Tres and Rocha, in eastern Uruguay, and the remaining case was in the Negro River fluvial plains, on the other side of the Cuchilla Grande hill range (200-500m altitude) that

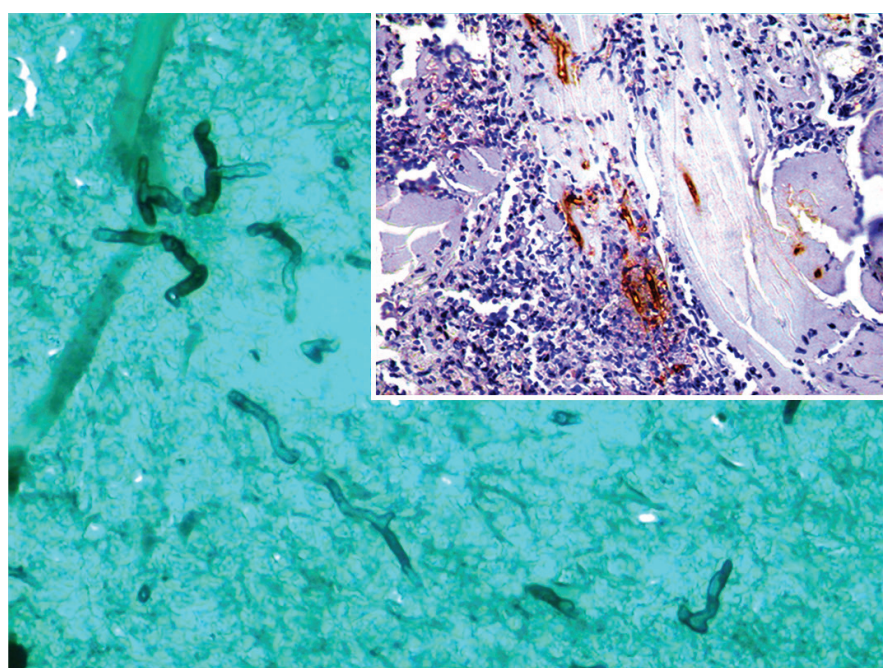

Fig.5. Case 7: Criollo mare. Non-septate intralesional hyphae, with discrete dilatations, and branching at $90^{\circ}$ (GMS). Inset: Immunostaining for Pythium insidiosum hyphae by IHC, obj.100x.

defined the western limit of the basin (Fig.7A). The soils corresponded to the Vergara (1 case), Río Branco (2 cases), Rincón de Ramírez (2 cases), San Luis (1 case) units in the eastern plains, and the Río Tacuarembó unit (1 case) on the coasts of the Tacuarembó River. The drainage and inundation geographic layers (Fig.7B,C) showed that all these areas are characterized by poor or very poor natural drainage (Classes 6, 7 and 8) and are annually exposed to long or very long flooding, or remain flooded most of the year (Molfino \& Califra 2004).

\section{DISCUSSION}

The epidemiology and the clinical, gross and histopathological findings in the seven studied horses were highly suggestive of Pythium insidiosum infection, which was confirmed by IHC in three animals. This technique is an effective and advantageous method when culture or isolation of the agent cannot be performed (Pedroso et al. 2009, Grooters 2013), but has the disadvantage that, because the hyphae are only found within the kunkers or into Splendore-Hoeppli foci (Mendoza et al. 1996), tissue sampling must be thorough. It had been observed that, in advanced stages of the disease, the exuberant formation of fibroplasia and granulation tissue made focal areas of necrosis distant from one another, making it difficult to obtain biopsies containing a sufficient quantity of kunkers for IHC diagnosis (Mendoza et al. 1996, Reis \& Nogueira 2002). This is the reason for recommending the collection of several biopsies at different locations in the damaged tissue (Reis \& Nogueira 2002). Thus, the absence of IHC-positive hyphae in some cases in the present study may be explained by the occurrence of an excessive proliferation of scar tissue in horses sampled in an advanced stage of the disease or, as samples came from routine material, biopsies did not include enough areas of necrosis where the hyphae are mostly visualized. 

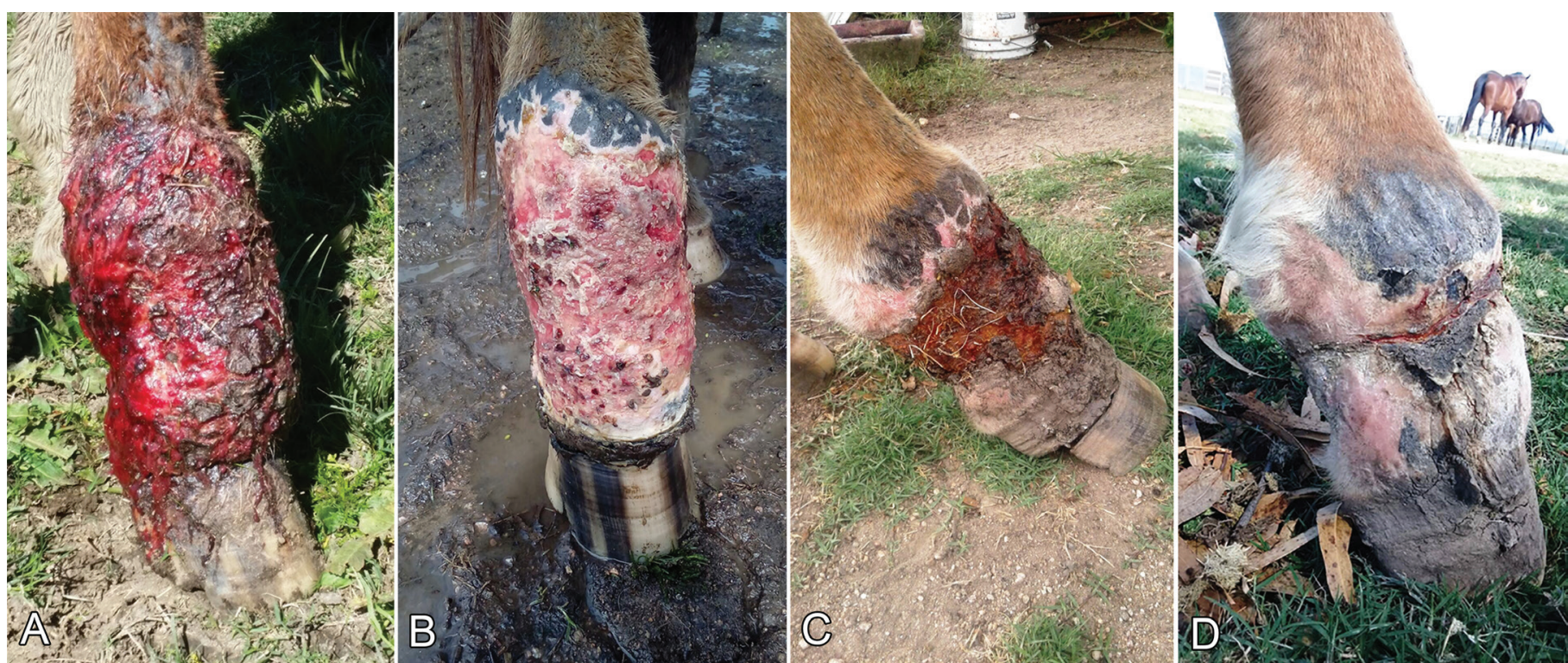

Fig.6. Case 7: Criollo mare treated with triamcinolone acetonide 50mg every 15 days. (A) Before starting treatment, (B) at 45 days, after 3 doses, (C) at 90 days, after 5 doses and (D) 1 year later.
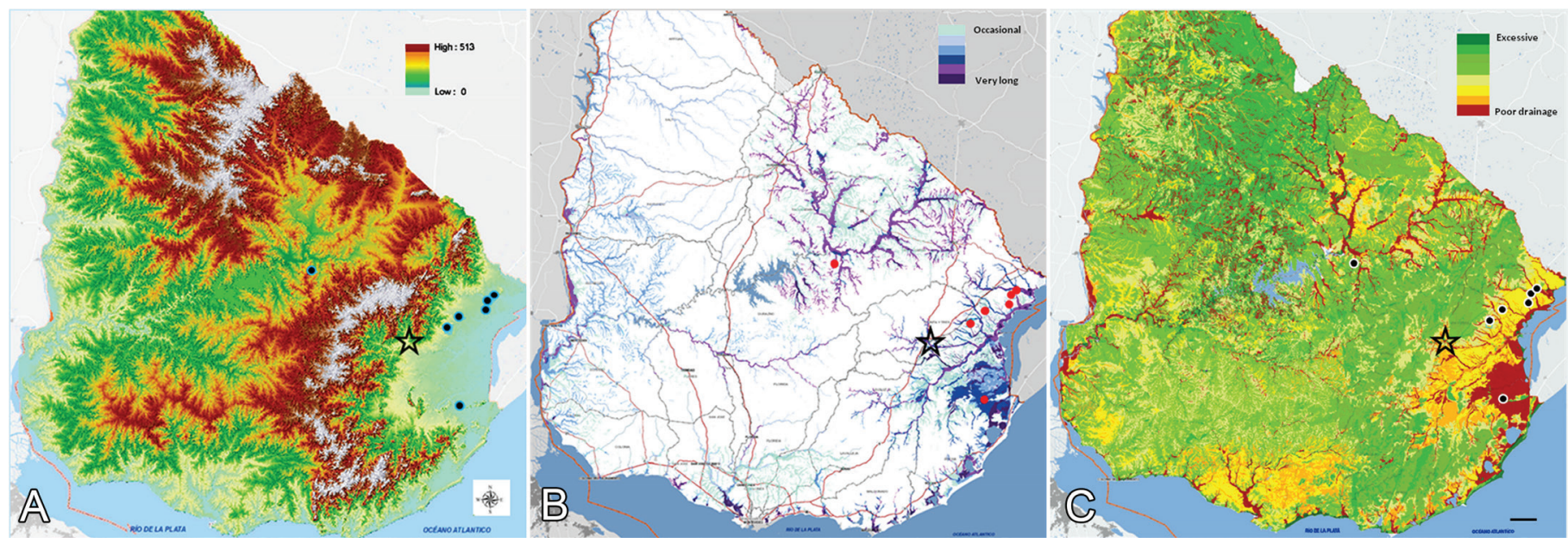

Fig.7. Geographic pattern of equine pythiosis in Uruguay. One-to-one point map with the following geographic layers superposed: (A) topographic layer (0 to 514 meters above sea level), (B) flooding layer (occasional to very long floodings), and (C) soil drainage layer (excessive to poor drainage). One point = one case. Maps obtained from <https://dgrn.mgap.gub.uy/js/visores/snia/\#>

In the differential diagnosis, cutaneous zygomycosis such as basidiobolomycosis (Basidiobolus ranarum) and conidiobolomycosis (Conidiobolus spp.), which cause cutaneous granulomatous lesions similar to equine pythiosis, should be mainly considered (Grooters 2013, Mauldin \& Peters-Kennedy 2015). Differentiation is important because the treatments and prognoses are different. In basidiobolomycosis, granulomatous lesions are most often found on the lateral aspects of the body due to the higher likelihood of these areas coming into contact with spore-containing soil or organic material when the animal lies on the ground, whereas conidiobolomycosis is mostly a nasopharyngeal infection, with or without dissemination to the external nares and face (Grooters 2013). In both diseases, kunkers are present, but are typically smaller $(<2 \mathrm{~mm})$ and lack the discrete, branched corallike shape of pythiosis (Miller \& Campbell 1984, Mauldin \& Peters-Kennedy 2015).
Microscopically, the diameter of the hyphae is significantly larger in Basidiobolus sp. and Conidiobolus sp. than in P. insidiosus, making them easily located on HE and PAS-stained histological sections (Miller \& Campbell 1984). In addition, right-angled hyphae are considered typical of P. insidiosum (Mendoza et al. 1996). Thus, the pathological and histopathological findings of the present cases are all indicative of Pythium insidiosum infection.

The successful use of triamcinolone acetonide has previously been reported in the treatment of equine cutaneous pythiosis (Cuero-Castilla \& Mendoza-Espinoza 1985 apud Mendoza et al. 1996, Cardona-Álvarez et al. 2016). Our experience with only one horse in the final phase of the disease confirmed these results. As surgical removal would be ineffective and pythiosis vaccines have not yet been approved in Uruguay, we decided to administer $50 \mathrm{mg}$ IM triamcinolone acetonide biweekly, 
as previously recommended (Cardona-Álvarez et al. 2016). The treatment began practically in the final phase of the disease when the animal was cachectic and very weak, and despite the large granulomatous ulceration around a distal leg, re-epithelization practically closed the wound after 1 year. The reasons for this potent curative effect of triamcinolone acetonide in the case of equine cutaneous pythiosis are uncertain. Unfortunately, we did not histologically follow the healing process. Triamcinolone acetonide inhibits eosinophil migration, reduces blood and tissue eosinophilia, and significantly enhances spontaneous eosinophil apoptosis (Zhang et al. 2000, Kankaanranta et al. 2005). In horses, triamcinolone is commonly used for the relief of itching and inflammation associated with a wide variety of eosinophilic skin conditions, such as eosinophilic granuloma, insect bite hypersensitivity, eosinophilic axillary nodular necrosis, habronemiasis, and even mastocytoma, among others (Scott \& Miller Junior 2011). It has been proposed that exoantigens of $P$. insidiosum trigger a TH2 immune response as an evolutionary strategy for recruiting eosinophils and mast cells; these may worsen inflammation and secure the proliferation and survival of hyphae inside the eosinophilic necrosis foci (kunkers). On the other hand, cytoplasmic immunogens stimulate a protective TH1 response and the recruitment of macrophages and lymphocytes, which may result in death of the organisms and clinical remission (Mendoza \& Newton 2005). Therefore, the high efficacy of triamcinolone for P. insidiosum infection in horses could be explained by its ability to modulate the immune response or inhibit the overwhelming number of degranulated eosinophils, limit the eosinophil-mediated tissue necrosis, decrease hyphae viability, and promote a rapid resolution of the eosinophilic inflammation. Other therapeutic studies are necessary, but our results suggest that an early histological diagnosis and treatment with triamcinolone acetonide would prevent the death of many horses in the endemic area.

In the present study, almost all cases of pythiosis occurred in the lower plains of the Merin lagoon basin, the largest wetland area in Uruguay (wetlands represent $4.5 \%$ of Uruguay's area), which is transboundary with the counties of Rio Grande do Sul, Brazil, where equine pythiosis is clinically and serologically highly prevalent (Marcolongo-Pereira et al. 2012, Weiblen et al. 2016). Agroecologically, the eastern wetland is characterized by spring-summer growing grassland, rice-growing or rice-livestock farming systems, a high density of grazing horses ( $>3.08 / \mathrm{sq} \mathrm{km}$; OIE 2017), a humid subtropical climate and a dense network of rivers and small streams where soil humidity is permanent during a large part of the year and hydrophilic vegetation has adapted to recurrent or permanent flooding (Clara \& Maneyro 1999); these environmental conditions are all ideal for the occurrence of equine pythiosis. Pythium insidiosum is a generalist pathogen, and ecological niche models predict its potential circulation through large areas in Rio Grande do Sul, Brazil, and Uruguay (Machado et al. 2018). In the present study, one case occurred in the fluvial wetlands of the Negro/Tacuarembó Rivers, but the disease might occur in other riverine wetlands of the country, such as the Carrasco/Santa Lucia plains (south of the country), lower reaches of the Uruguay River (Farrapos wetlands, southwest), or Queguay, Arapey and Dayman Rivers (northwest; Dr. Deborah César \& Rodolfo Rivero, pers. comm.
2018), although horse density is much lower in these areas $(<1.05 / \mathrm{sq} \mathrm{km}$; OIE 2017). Thus, the eastern wetlands appear to be the endemic ecological niche of equine pythiosis in Uruguay, although sporadic cases may occur in marshes and river plains in other parts of the country.

\section{CONCLUSION}

Pythiosis by Pythium insidiosum is an endemic disease of grazing horses in the wetland ecosystem of eastern Uruguay. Early treatment with triamcinolone acetonide is promising, but requires more research.

\section{REFERENCES}

Alfaro A.A. \& Mendoza L. 1990. Four cases of equine bone lesions caused by Pythium insidiosum. Equine Vet. J. 22(4):295-297. <http://dx.doi. org/10.1111/j.2042-3306.1990.tb04273.x><PMid:2209529>

Allison N. \& Gillis J.P. 1990. Enteric pythiosis in a horse. J. Am. Vet. Med. Assoc. 196(3):462-464. <PMid:2298680>

Azevedo M.I., Pereira D.I.B., Botton S.A., Costa M.M., Mahl C.D., Alves S.H. \& Santurio J.M. 2012. Pythium insidiosum: morphological and molecular identification of Brazilian isolates. Pesq. Vet. Bras. 32(7):619-622. <http:// dx.doi.org/10.1590/S0100-736X2012000700005>

Brown C.C., McClure J.J., Triche P. \& Crowder C. 1988. Use of immunohistochemical methods for diagnosis of equine pythiosis. Am. J. Vet. Res. 49(11):18661868. <PMid:3073678>

Cardona-Álvarez J.A., Vargas-Viloria M. \& Perdomo S. 2014. Frecuencia de Pythiosis cutánea en caballos de producción en explotaciones ganaderas de Cordóba, Colombia. Revta Med. Vet. Zoot. 61(1):31-43. <http://dx.doi. org/10.15446/rfmvz.v61n1.43882>

Cardona-Álvarez J.A., Vargas-Vilória M. \& Patarroyo-Salcedo J. 2016. Pythiosis cutánea en equinos tratados con acetonida de triamcinolona. Parte 1. Caracterización clínica. Revta MVZ Córdoba 21(3):5511-5524. <http:// dx.doi.org/10.21897/rmvz.825>

Cardona-Álvarez J.A., Vargas-Vilória M. \& Patarroyo-Salcedo J. 2017. Pythiosis cutánea en equinos tratados con acetonida de triamcinolona. Parte 2. Descripción histológica e histoquímica. Revta MVZ Córdoba 22(1):56385652. <http://dx.doi.org/10.21897/rmvz.924>

Chaffin M.K., James S. \& McMullan W.C 1995. Cutaneous pythiosis in the horse. Vet. Clin. N. Am., Equine Pract. 11(1):91-103. <http://dx.doi.org/10.1016/ S0749-0739(17)30334-6><PMid:7634168>

Clara M. \& Maneyro R. 1999. Humedales del Uruguay, el ejemplo de los humedales del Este, p.68-80. In: Malvarez A.I. (Ed.), Tópicos sobre Humedales Subtropicales y Templados de Sudamérica. MaB UNESCO, Montevideo.

Dória R.G., Carvalho M.B., Freitas S.H., Laskoski L.M., Colodel E.M., Mendonça F.S., Silva M.A., Grigoletto R. \& Fantinato Neto P. 2015. Evaluation of intravenous regional perfusion with amphotericin B and dimethylsulfoxide to treat horses for pythiosis of a limb. BMC Vet. Res. 11(152):1-7. <http:// dx.doi.org/10.1186/s12917-015-0472-z> <PMid:26174778>

Dutra F., Quinteros C. \& Romero A. 2012. Pitiosis equina. Arch. Vet. Este $4(12 / 13): 12-14$

Dutra F., Quinteros C., Romero A. \& Briano C. 2014. Pitiosis (Pythium insidiosum) en yegua Arabe. Arch. Vet. Este 6(20/21):12-14.

Gaastra W., Lipman L.J., De Cock A.W., Exel T.K., Pegge R.B., Scheurwater J., Vilela R. \& Mendoza L. 2010. Pythium insidiosum: an overview. Vet. Microbiol. 146(1/2):1-16. <http://dx.doi.org/10.1016/j.vetmic.2010.07.019> <PMid:20800978>

Goad M.E. 1984. Pulmonary pythiosis in a horse. Vet. Pathol. 21(2):261-262. <http://dx.doi.org/10.1177/030098588402100224><PMid:6730214> 
Grooters A.M. 2013. Pythiosis and zygomycosis, p.415-421. In: Sellon D.C. \& Long M.T. (Eds), Equine Infectious Diseases. 2nd ed. Saunders Elsevier, St Louis.

Kankaanranta H., Moilanen E. \& Zhang X. 2005. Pharmacological regulation of human eosinophil apoptosis. Curr. Drug Targets Inflamm. Allergy 4(4):433-445. <http://dx.doi.org/10.2174/1568010054526395> $<$ PMid:16101520>

Machado G., Weiblen C. \& Escobar L.E. 2018. Potential distribution of Pythium insidiosum in Rio Grande do Sul, Brazil, and projections to neighbour countries. Transbound. Emerg. Dis. 65(6):1671-1679. <http://dx.doi. org/10.1111/tbed.12925><PMid:29920968>

Marcolongo-Pereira C., Sallis E.S.V., Raffi M.B., Pereira D.I.B., Hinnah F., Coelho A.C.B. \& Schild A.L. 2012. Epidemiology of equine pythiosis in southern of Rio Grande do Sul State, Brazil. Pesq. Vet. Bras. 32(9):865-868. <http:// dx.doi.org/10.1590/S0100-736X2012000900009>

Márquez A., Salas Y., Canelón J., Perazzo Y. \& Colmenárez V. 2010. Descripción anatomopatológica de pitiosis cutánea en equinos. Revta Fac. Ciênc. Vet. UCV 51(1):37-42.

Martins T.B., Kommers G.D., Trost M.E., Inkelmann M.A., Fighera R.A. \& Schild A.L. 2012. A comparative study of the histopathology and immunohistochemistry of pythiosis in horses, dogs and cattle. J. Comp. Pathol. 146(2/3):122-131. <http://dx.doi.org/10.1016/j.jcpa.2011.06.006><PMid:21824626>

Mauldin E.A. \& Peters-Kennedy J. 2015. Integumentary system, p.509-736. In: Maxie G. (Ed.), Jubb, Kennedy and Palmer's Pathology of Domestic Animals. Vol.1. 6th ed. Saunders Elsevier, St Louis.

Mendoza L. \& Newton J.C. 2005. Immunology and immunotherapy of the infections caused by Pythium insidiosum. Med. Mycol. 43(6):477-486. <http://dx.doi.org/10.1080/13693780500279882> <PMid:16320491>

Mendoza L., Ajello L. \& McGinnis M.R. 1996. Infections caused by the oomycetous pathogen Pythium insidiosum. J. Mycol. Med. 6(4):151-164.

Miller R.I. \& Campbell R.S. 1984. The comparative pathology of equine cutaneous phycomycosis. Vet. Pathol. 21(3):325-332. <http://dx.doi. org/10.1177/030098588402100310> <PMid:6730223>

Molfino J.H. \& Califra A. 2004. Evaluación del drenaje natural de las tierras del Uruguay (primera aproximación). Departamento Estudios Básicos de Suelos y Evaluación de Tierras, Dirección de Servicios Agrícolas (DSA), Dirección General de Recursos Naturales Renovables (RENARE), Ministerio de Ganadería, Agricultura y Pesca (MGAP), Montevideo. 17p. Available at <http://www.mgap.gub.uy/sites/default/files/ multimedia/2081_1376398259Drenajenaturaljulio04.pdf> Accessed on Nov. 30, 2018
Morton L.D., Morton D.G., Baker G.J. \& Gelberg H.B. 1991. Chronic eosinophilic enteritis attributed to Pythium sp. in a horse. Vet. Pathol. 28(6):542-544. <http://dx.doi.org/10.1177/030098589102800615><PMid:1771746>

OIE 2017. World Organization for Animal Health. Available at <http://www. oie.int/wahis_2/public/wahid.php/Countryinformation/Animalpopulation> Accessed on Jan. 30, 2019.

Pedroso P.M.O., Bezerra Júnior P.S., Pescador C.A., Dalto A.G.C., Costa G.R., Pereira D.I.B., Santurio J.M. \& Driemeier D. 2009. Diagnóstico imunohistoquímico de pitiose cutânea em equinos. Acta Scient. Vet. 37(1):49-52. <http://dx.doi.org/10.22456/1679-9216.16187>

Pereira D.B. \& Meirelles M.A. 1997. Pitiose, p.457-466. In: Riet-Correa F., Schild A.L., Lemos R.A.A. \& Borges J.R.J. (Eds), Doenças de Ruminantes e Eqüídeos. Vol.1. 3rd ed. Palloti, Santa Maria.

Reis Junior J.L. \& Nogueira R.H.G. 2002. Estudo anatomopatológico e imunoistoquímico da pitiose em eqüinos naturalmente infectados. Arq Bras. Med. Vet. Zootec. 54(4):358-365. <http://dx.doi.org/10.1590/ S0102-09352002000400005>

Santos C.E.P., Santurio J.M., Colodel E.M., Juliano R.S., Silva J.A. \& Marques L.C. 2011. Contribuição ao estudo da pitiose cutânea em equideos do Pantanal Norte, Brasil. Ars Vet. 27(3):134-140.

Scott D.W. \& Miller Junior W.H. 2011. Equine Dermatology. W.B. Saunders, St Louis. 536p.

SNIA 2018. Sistema Nacional de Información Agropecuaria, Uruguay. Available at <https://dgrn.mgap.gub.uy/js/visores/snia/\#> Accessed on Nov. 30, 2018

Souto E.P.F., Maia L.A., Olinda R.G., Galiza G.J.N., Kommers G.D., Miranda-Neto E.G., Dantas A.F.M. \& Riet-Correa F. 2016. Pythiosis in the nasal cavity of horses. J. Comp. Pathol. 155(2/3):126-129. <http://dx.doi.org/10.1016/j. jсpa.2016.06.005><PMid:27406311>

Weiblen C., Machado G., Jesus F.P.K.D., Santurio J.M., Zanette R.A., Pereira D.S. \& Botton S.D.A. 2016. Seroprevalence of Pythium insidiosum infection in equine in Rio Grande do Sul, Brazil. Ciência Rural 46(1):126-131. <http:// dx.doi.org/10.1590/0103-8478cr20150056>

White S.D., Ghoddusi M., Grooters A.M. \& Jones K. 2008. Cutaneous pythiosis in a California nontravelled horse. Vet. Dermatol. 19(6):391-394. <http:// dx.doi.org/10.1111/j.1365-3164.2008.00690.x><PMid:18699814>

Zhang X., Moilanen E. \& Kankaanranta H. 2000. Enhancement of human eosinophil apoptosis by fluticasone propionate, budesonide, and beclomethasone. Eur. J. Pharmacol. 406(3):325-332. <http://dx.doi.org/10.1016/S00142999(00)00690-7><PMid:11040338> 